\title{
The theological ethics of human enhancement: Genetic engineering, robotics and nanotechnology
}

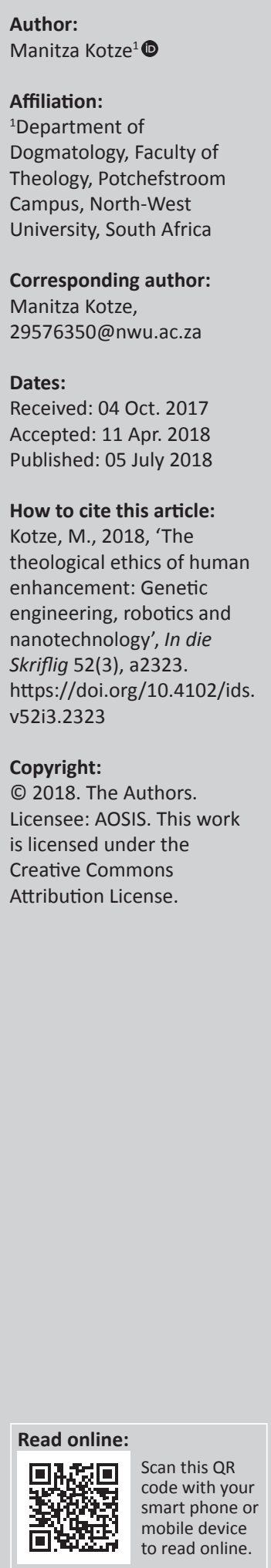

The recent advances made by biotechnology have been swift and sundry. Technological developments seem to happen sooner than they can be ethically reflected upon. One such trend is the endeavours launched to try and enhance human beings and what it means to be human with movements such as transhumanism, advocating strongly that we should overcome our natural limitations by any means available. With both critics and advocates utilising the expression 'playing God', the question of human enhancement is one in which the interplay between church and society comes compellingly to the fore. In this contribution, I wish to examine the bioethical challenges that technologies such as genetic engineering, robotics and nanotechnology raise, specifically from a theological perspective on human enhancement and indicating some paths that future research might take. Christian anthropological views on what it means to be human, especially to be created imago Dei [to the image of God] will provide the doctrinal and theological support to this contemplation.

\section{Introduction}

The advances made by biotechnology in recent years have been rapid and very diverse. From genetically engineered crops to the possibilities of reproductive cloning being discussed, technological developments seem to happen sooner than they can be ethically reflected upon. One such trend is the endeavours launched to try and enhance human beings and what it means to be human. This appeals with movements such as transhumanism, advocating strongly that we should overcome our natural limitations by any means available, whether that is changing the makeup of our genes through genetic engineering, using nanotechnology to, for example significantly prolong our lifespan, and robotics to improve our current constitution, or even in its most extreme form, to upload our consciousness into supercomputers.

The World Transhumanist Association released a statement in 2008, claiming: 'We support the development of access to new technologies that enable everyone to enjoy better minds, better bodies and better lives' (World Transhumanist Association 2008, [original emphasis]).

\section{Ivana Greguric (2014) explains:}

The usage of bioelectronics enables us to connect new technologies with human nervous system on a higher-functioning level, nanotechnologies and nanomachines coupled with genetic engineering can affect biological changes within the cells, bringing further changes in the human biological structure. There are two dominant courses of improving and reshaping the human body. On the one hand, the human body is 'dematerialised' in the infinite space-time of the virtual world, using digital information, and on the other hand, the technical implants and artificial additions turn a man into a partially artificial being - cyborg, with a tendency for replacing all organic bodily parts and their functions, and creating a robot. (p. 133)

Transhumanism, John Gleaves (2017:92) indicates, can be traced back to Julian Huxley's 1957 essay by the same name, 'where he introduces the idea that humans could transcend their current limits through biological intervention'. Christoph Lüthy and Bert-Jaap Koop (2013:2) indicate that statements such as the one that the World Transhumanist Manifesto (1998) opens with, namely that ' $[h]$ umanity stands to be profoundly affected by science and technology in the future', could be rewritten in the present tense. They ask the following questions: Does rising life expectancies not already attest to remarkable achievements in battling the course of human aging? Are our intellectual limitations not already compensated for by electronic devices and psychopharmaceuticals? Is involuntary suffering not already being alleviated or, to a large degree, eradicated away by modern medical treatment? 
It is beyond the scope of what I will try to discuss in this contribution to present a detailed investigation into what and how these disciplines aim to enhance humanity. With one of the aims of this article, namely to indicate gaps for future research, I accordingly mention this to take note of for some future investigations. Future studies could examine in more detail each of these fields and their claims in terms of enhancing what it means to be human.

When within theological fields, bioethical reflection takes into account policy, public opinion, public trust and views from medical science, among others, the questions that are raised are decisively within the public realm. In this sense, this contribution can be said to also fall within the field of public theology to which I will turn to shortly.

With both critics and advocates utilising the expression 'playing God', the question of human enhancement is one in which the interplay between church and society comes compellingly to the fore. In this contribution, I wish to examine the bioethical challenges that technologies such as genetic engineering, robotics and nanotechnology raise, specifically from a theological perspective on human enhancement. Christian anthropological views on what it means to be human, especially by being created imago Dei, will provide the doctrinal and theological support to this contemplation. In this contribution, I will therefore not be arguing a specific position or perspective, but rather aim to put some of the important issues on the table and identify areas that could, and I would contend, should, be examined and discussed further. I will do so by focusing on two, rather broad areas. In the first place, I will discuss human biotechnological enhancements in general and indicate some of the questions that they raise. I will then begin to investigate how Christian anthropology could help to articulate a public and prophetic response.

\section{Ethical issues in human enhancement}

The term enhancement, as such, can be said to be also theological in nature, if we consider the transformative and regenerative work of the Holy Spirit. Enhancement by means of biotechnology, is a different form of 'improving' ourselves, however.

The language and terminology employed to discuss the changes promised by biotechnology, robotics and nanotechnology are also of note. In the English, the expression usually in use is 'human enhancement' - a phrase that appears to suggest the betterment of functions and abilities that already exist. The alternate expressions such as 'artificial human beings' or 'transhuman', however suggest a troublesome disjointedness between the present human forms created naturally and artificial ones in the future. The German expression die Perfektionierung des Menschen [perfectioning of human beings] on the other hand, like 'enhancement', contains constructive inferences of development, but not of discontinuity. The phrase de maakbare mens [makeable human being], mostly used in Dutch and Flemish discussions, delivers a term that is much more neutral in terms of the implied values and can be used to refer to any of the contemporary methods used to change human nature, of which not all need to intend enhancement (Lüthy \& Koop 2013:3).

What exactly would qualify as enhancement is one of the first issues raised by the development of this form of biotechnology. What types of interventions should be discussed under the heading of enhancement, and which can safely be termed therapeutic? ${ }^{1}$ These intercessions, Gleaves (2017:93) states, can include mechanical, biochemical, surgical or genetic alterations that result in states of 'better than well'. David Kirchhoffer (2017:375) defines enhancement as 'making something better than it was before' and states that it is the 'technological, genetic, or chemical improvements to normal, healthy human beings'. 'Enhancement', he continues, 'is therefore distinct from therapy, which would involve making some "abnormality" more "normal". Enhancement is about making something better than "normal".' For the purposes of this contribution, I will be following Kirchhoffer's definition, but further research might do well to further investigate the blurred lines between what constitutes therapy and enhancement, respectively. Clearly, the exact same treatment could be administered with different effects, depending on the recipient. Improving the eyesight of one person by $25 \%$ might render that person to see 'normally' without the wearing of glasses or contact lenses. Performing the exact same treatment on an individual who can already see well without ocular assistance, would therefore enhance that person's eyesight beyond what is 'normal'.

Enhancement, per se, wanting to be or become 'better', can also be said to part of what it means to be human. Mark Coeckelbergh (2013) states that we always 'struggle against our condition and try to improve it':

\footnotetext{
... we do not want to be vulnerable, or at least not as vulnerable as we are (now). We resist. We rebel. We design and use technology to decrease our vulnerability. For example, we use medical knowledge and medical technology to prevent disease and postpone death. And we use all kinds of safety and security technologies to decrease our vulnerability. (p. 4)
}

The refusal to admit to the unavoidable, Coeckelbergh (2013:3) continues, is a result of the human ability to imagine: 'it is because we can imagine better worlds that we do not accept the view that we live in "the best of all possible worlds"'. Our imagination also causes our attempts to develop and enhance our circumstances and lead us to

1.The President's Council on Bioethics, in their report, Beyond Therapy (2003), defined the distinction between therapy and enhancement as follows:

'Therapy', on this view as in common understanding, is the use of biotechnical power to treat individuals with known diseases, disabilities, or impairments, in an attempt to restore them to a normal state of health and fitness. 'Enhancement', by contrast, is the directed use of biotechnical power to alter, by direct intervention, not disease processes but the 'normal' workings of the human body and psyche, to augment or improve their native capacities and performances. (p. 13) 
endeavour to produce an improved world also making use of technology. As human beings, we have always tried to lessen our helplessness, our weaknesses, our vulnerabilities (Coeckelbergh 2013:3).

In a FAQ document for the World Transhumanist Association (now Humanity+), Bostrom (2003) defines transhumanism as follows:

Transhumanism is a way of thinking about the future that is based on the premise that the human species in its current form does not represent the end of our development but rather a comparatively early phase. We formally define it as follows:

(1) The intellectual and cultural movement that affirms the possibility and desirability of fundamentally improving the human condition through applied reason, especially by developing and making widely available technologies to eliminate aging and to greatly enhance human intellectual, physical, and psychological capacities. (2) The study of the ramifications, promises, and potential dangers of technologies that will enable us to overcome fundamental human limitations, and the related study of the ethical matters involved in developing and using such technologies. (p. 4, quoted in Coeckelbergh 2013:9)

The aspirations of transhumanists have led to a debate with highly polarised sides, with those that defend and try to protect human nature, on the one side, and transhumanists who want to change it, on the other. Transhumanists reproach their adversaries on the other side of the discussion for being irrationally conservative (Coeckelbergh 2013:20).

On the side of the defenders of transhumanism, there are a few scholars who view the meeting of technologies related to humanity in the immanent future and the advent of superman' (Lüthy \& Koop 2013:5) optimistically. Proponents often use a three-pronged argument: firstly, to emphasise all the possible benefits that enhancement could result in such as 'physical, cognitive, social, and moral improvement over our current, naturally given, condition' (Eberl 2014:292-293). Secondly, they further presume on the side of the liberal notion of individual autonomy, to the extent that the responsibility of proof should be with those who seek to limit the liberty of people seeking to enhance themselves or their children (Eberl 2014:292-293). A prominent example of this is Colin Gavaghan (2007) who argues in Defending the genetic supermarket that individuals have the right to decide for themselves whether and how to employ enhancement technologies. This group of advocates not only includes innovative and ground-breaking scientists like Kevin Warwick, but also visionaries like Ray Kurzweil and Ramez Naam. In addition, Harris also postulates that we have a moral duty to enhance ourselves (Lüthy \& Koop 2013:5), even if we were to make mistakes along the way (Coeckelbergh 2013:20). Harris (2007:36) even claims: 'Enhancements are so obviously good for us that it is odd that the idea of enhancement has caused ... so much suspicion, fear, and outright hostility.' The decisions regarding what to enhance, he claims, should be left to the liberty of individuals (Harris 2007). Thirdly, they (Eberl 2014) also argue that human nature:

as given, is not fixed but malleable and that the application of human intelligence is likely to result in superior alterations to the human form than the 'blind' process of continued biological evolution. (p. 293)

As transhumanist Bostrom (2003) puts it:

Transhumanists view human nature as a work-in-progress, a half-baked beginning that we can learn to remold in desirable ways. Current humanity need not be the endpoint of evolution. Transhumanists hope that by responsible use of science, technology, and other rational means we shall eventually manage to become post-human, beings with vastly greater capacities than present human beings have. (p. 493)

A further argument, as Gregory Stocks (2002:10) remarks, that is often used by proponents is that the development of the types of technologies that will alter human beings 'cannot be stopped anyway'.

There are also scholars who view enhancement technologies as holding the risk to become dangerous, but this does not necessarily have to rule it out. Liberal eugenics that still respects pluralism and, as Nicolas Agar (2004) puts forward, is possible. Peter Singer (2003) claims that human enhancement should not be left to the free marks and calls for the intercession of the state, whereas Ronald Bailey (2005) argues that we will learn by trial and error.

In contrast, opponents would postulate that enhancing human beings should not only be regulated, but forbidden outright. Coeckelbergh (2013) further presents a summary of some of the opposing views:

Habermas (2001) sees a threat to human being and human dignity in the emergent biotechnological possibilities, as does Smith (2004); Fukuyama (2004) relies on the notion of human nature to argue in favour of therapy but against enhancement. McKibben (2003) sketches a horrific future and claims that our current technology is already enough that we should restrain ourselves and stop further developing the technologies. Elliott (2003) links human enhancement to a culture of obsessive happiness seeking by medical means. And Dupuy (2008) thinks we must 'defend' humanism against the excesses of science and technology. (p. 20)

Future studies can engage with each of these positions in more detail, but, in short, the main questions that enhancement raises, in my view, is in terms of human suffering, human mortality, human vulnerability and human limitations. Do we need these conditions to be and remain human? Do we need these situations and characteristics from the perspective of Christian anthropology?

One such question is articulated by Gleaves (2017:94) as: 'To what degree do humans have an obligation to accept aging and death as a natural part of what it means to be human?' 
There are different positions ${ }^{2}$ regarding the notion of the development and implementation of interventions against declines related to aging that could be adopted, but all of them are attempts to answer this question. If we accept the norms for chronological octogenarians to establish what could be viewed as 'normal', then any declines in performance associated with age should likewise be accepted as normal and any effort to intervene counts as an effort toward enhancement. This is an area that is underdeveloped in ethical and theological reflection on enhancement. Gleaves (2017) remarks:

Surprisingly, I could find few (in fact, only one) article that ventures into the issue of aging, ethics, and human performance (Juengst et al. 2003). Although philosophers have enjoyed toying with notions of immortality, the real questions about the ethics of human performance and aging have appeared to escape serious attention. (p. 94)

Stock (2002:9) also refers to the fight against mortality as being 'an ancient dream'. Numerous scientists, Greguric (2014:141) indicates, caution that nanotechnology could make the fusion of molecules into greater structures possible and thus, 'radically change certain branches of science, medicine, electronics and influence society and human identity'. Accordingly, with the advent of enhancement technologies such as nanotechnology, the makeup of human identity and human nature are coming into question.

These are clearly issues that belong firmly in the public realm. Questions about biotechnology whether we should develop and also use technology that alters our genetic makeup as well as attempts to change human nature and potentially what it means to be human, are ethical, Coeckelbergh indicates, but also political. While new dangers and vulnerabilities that ensue because of technology could cause us personal worry, because their consequences and implications are also ethical and social, they can also be termed 'a matter of public and societal concern to such an extent that according to Ulrich Beck, we live in a "risk society"'. Beck (1992) defines this risk society as one that is more and more concerned with risk, especially the risks created by modernisation itself. New risks are invented, created and produced, as new technologies are invented and new artefacts are produced.

I therefore now turn to the engagement of these issues, also within theological discourse, by focusing on Christian anthropology.

\section{Christian anthropology}

In discussing human nature, Coeckelbergh (2014:23) argues that biology teaches us the sense of natural evolution: 'all

\footnotetext{
2.If we also dismiss enhancements as generally unethical, we seemingly consign ourselves to passively accept aging and death as a natural part of what it means to be human and only seek treatments to return to age-appropriate function. On the other hand, we could adopt a view that sees aging as normal, but seeks performance other hand, we could adopt a view that sees aging as normal, but seeks performance
enhancements as a remedy. This more moderate approach acknowledges ageassociated decline is normal, though encourages interventions that count as enhancements over the aging norms. Finally, a third position could assert that any enhancements over the aging norms. Finally, a third position could assert that any
age-related decline counts as an undesirable accident of nature that should be age-related decline counts as an undesirable accident
cured, using every available tool. (Gleaves 2017:94)
}

organisms, including humans, change over time as a result of natural selection and (according to contemporary evolution theory) mutation and genetic drift'. Additionally, our perspectives of humanity, he (Coeckelbergh 2013:24) continues, are established by our social and cultural environment, as the social sciences have further taught us. Why should human nature be any different, he then asks?

For Christian anthropology, however, the most important starting point for any discussion of humanity, including human nature, would be that human beings are created by the triune God, created in God's image - imago Dei. Nico Vorster (2007:19) indicates that the imago Dei is a relational notion that articulates the creational state of the human being in relation to God, other humans and the non-human creation. Jürgen Moltmann (1999) summarises this well when he puts forward:

The fact that all human beings are made in the image of God is the foundation of human dignity. Human beings are intended to live in this relation to God. That gives their existence its inalienable, transcendent depth dimension. In their relationship to the transcendent God, human beings become persons whose dignity must not be infringed. (p.122)

\section{Human dignity}

In terms of the role that the notion of human dignity plays in enhancement discourses, the discussion can, in general, be considered as being between two distinct groups: 'Nick Bostrom(himselfa transhumanist)calls them Bioconservatives and Transhumanists; others, such as Roduit, Baumann, and Heilinger talk about bioconservatives and bioliberals' (Kirchhoffer 2017:376). Within these two camps, both sides utilise the concept of human dignity: one side claiming that enhancement encroaches on the dignity of the individual being treated, and the other that failing to make use of the available technology to enhance is rather the violation of dignity. Within both perspectives, how human dignity is understood is of importance. The insistence that dignity is an essential characteristic of being human could be done with reference to either species membership ${ }^{3}$ or abilities. ${ }^{4}$ Understanding dignity as something mutable to be developed, actualised or lost could be based on either the

3.One argument offered frequently, especially in theological discussions of human dignity, would argue that all human beings have innate dignity, purely because of belonging to the human species. Human dignity can then be used, as Fukuyama (2002) and Agar (2010) does, to argue against enhancement, or at as Fukuyama (2002) and Agar (2010) does, to argue against enhancement, or at
least radical enhancement, by asserting that such alteration of the human least radical enhancement, by asserting that such alteration of the human genome would damage the dignity of those being enhanced. A transhumanist
position such as the one advocated by Ronald Sandler and John Basl (2010:63position such as the one advocated by Ronald Sandler and John Basl (2010:63-
$66)$, however, would be able to argue in favour of enhancement by claiming $66)$, however, would be able to argue in favour of enhancement by claiming
that it 'values the human species so much that enhancement is necessary for the very survival of the species in the face of the inevitable advance of technology'

4.This school of thought argues that there are specific capacities that are unique to human beings and that dignity is grounded on these capacities. Different capacities have been identified in different discourses, but examples include rationality, autonomy, conscience and the capacity to love. It is important to note that the possession of the capacity is stressed; not how well developed it is. Therefore from the perspective of transhumanism human dignity is only violated if these capacities the perspective of transhumanism, hum are reduced or eliminated. The argument could benetic enhancement may well also enhance these capacities in such a manner that the dignity of the individual being enhanced and also heightened as a result. On the other hand, it would also be possible to argue against enhancement by vitue of dignity, as biotechnological intervention might 'change a capacity so fundamental to our humanity that one could no longer speak of the new being as having human dignity' (Kirchhofffer 2017:377). 
category of selfworth ${ }^{5}$ or behaviour ${ }^{6}$ (Kirchhoffer 2017:376). The discourse on human dignity and the role that it can play in also developing the arguments used both in favour of and against biotechnological enhancements, is another area that future research could focus on rewardingly and prolifically.

In terms of anthropology, the capacities perspective seems to be the best developed. Jason Eberl (2014:290), for example expounds upon Thomas Aquinas's understanding of human nature, underlining a number of crucial attributes that human beings usually have in common; attributes that serve to define us as persons with 'inviolable moral status'. These characteristics, which delineate human nature, include 'selfconscious awareness, capacity for intellective thought, and volitional autonomy' (Eberl 2014:290) and inform the ethical valuation of enhancing human beings in different manners. Assuming that, they can be proven to be harmless and effective, he continues. Several forms of enhancement may be described as not only acceptable from a moral perspective, but even appropriate from a point of view that seeks to heighten human flourishing. Eberl (2014:290) views the improving of immune systems or memory capacity as examples of this type of enhancement.

It is also possible, however, that some types of enhancement might be dangerous in terms of detracting from the flourishing of human beings or 'altering one's nature in ways that would lead to complicated social relationships with other human persons or diminishing one's moral agency' (Eberl 2014:290). These types of enhancements should not be engaged in or developed, Eberl contends. He includes efforts to try and enhance emotional reactions in this category.

One of the most well-known voices in the discussion on human dignity in terms of capacities is that of Martha Nussbaum. She (2002:129) mentions ten ${ }^{7}$ fundamental or core human capabilities which wields both moral and political claims on others to deliver the means for their actualisation. The first two of these capabilities are life and bodily health. While bodily health as a capability is essential, obviously to furthering life, it also has a more widespread value on its own, insofar as health also implies that an individual is not suffering from illnesses or injuries. Nussbaum's perspective, Eberl (2014:297) points out, agrees with 'the Thomistic natural

\begin{abstract}
5.This view is very similar to the capacities perspective but sees enhancement as either positive or negative according to the degree to which it assists in the either positive attainment of a sense of self-worth. Martha Nussbaum (2008) postulates that there is no sense in merely affirming the dignity of all human individuals without also being concerned with how those who are capable of experiencing their own dignity actually experience it for themselves in a subjective sense. Kirchhoffer (2017:378) clarifies that she does not thereby say that dignity should not also be affirmed in the third person sense, but that such 'affirmation has little meaning if we are not also concerned about how people who are capable of experiencing this dignity themselves do experience it'.
\end{abstract}

6.Kirchhoffer (2017:378) notes that this perspective views dignity 'as something that we acquire'. Human dignity is realised through moral behaviour.

7.Nussbaum (2006:76-78) presents 10 core human capabilities: 1. Life; 2. Bodily health; 3 . Bodily integrity, living with free movement, freedom from sexual assault and violence, and having opportunities for sexual satisfaction; 4 . The ability to use our senses and imagination, being able to experience and produce culture, freedom of expression and religion; 5. The ability to have emotions and attachments to people and things; 6. Being able to engage practical reason, reflecting on the planning of our lives; 7. Living with and toward others with imagination; 8. Living with other species, such as animals, plants and nature; 9. Play; 10 . Control over ou own environment. law ethic insofar as both see individual and collective human flourishing as the ultimate goal of moral action'. Both Nussbaum and Thomas also 'understand this ultimate goal to be reached through the actualization of natural human capabilities' (Eberl 2014:297).

Similar to human rights, Nussbaum (2006:78) considers that her list of capabilities 'can gather broad cross-cultural agreement', and explicitly grounds it in the notion of human dignity:

The basic intuitive idea of my version of the capabilities approach is that we begin with a conception of the dignity of the human being, and of a life that is worthy of that dignity. (Nussbaum 2006:74)

Coeckelbergh (2001) indicates, however, that if presented in the manner:

that the capabilities list is based on human dignity and on what we are as humans ... Nussbaum's argument could be easily misunderstood as saying that the concept of human dignity and the related capabilities are given to us in a priori reflection. (p. 84)

Actualy, Nussbaum denies such an abstract foundation and instead states that 'the list is a matter of (real-world) political agreement' (Coeckelbergh 2011:84). 'Frequently', she (Nussbaum 2006) indicates,

we inform ourselves about alternative possibilities by imagining the form of life that these possibilities would construct, asking ourselves what suffering or flourishing there would be in lives governed by these political principles. (p. 353)

Bostrom (2005:212) contends that enhancement is not a risk to either an individual's freedom or dignity, as an enhanced person would have no less freedom and their options would be more rather than less. The improvements would actually increase their basic capabilities. He continues to note:

Transhumanists ... insist that dignity, in its modern sense, consists in what we are and what we have the potential to become, not in our pedigree or our causal origin. What we are is not a function solely of our DNA but also of our technological and social context. Human nature in this broader sense is dynamic, partially human-made, and improvable. (p. 213)

Human dignity can thus also be used by both sides of the argument which makes this an especially rich field for future inquiry. Human dignity can also be said to be part and parcel of the way in which Christian anthropologies have been regarded, both traditionally and in more recent works. In Christian anthropology, however, there is a different perspective than those raised previously. 'Without thereby in any sense detracting from the full creaturely reality of being human', Gerrit Berkouwer (1962) states:

we may say that we never encounter in the Bible an independently existing, abstract, ontological structural interest in man. In the Bible, man is indeed analysed, but in a very special sort of analysis, a basic sort which exposes man in his evil and apostasy, in his mortality and rebellion, his sin and guilt. It deals fully with the actuality of humanness, but it is an actuality before God. (p. 139 ff.) 
Human beings are intended to live in this relation to God, and it is this factor that gives human existence its 'inalienable, transcendent depth dimension' (Moltmann 1999:122).

\section{Human vocation}

In Christian anthropology, identity is then inherently linked with calling. Steve de Gruchy (2003) contended:

It is important to recognise that in both creation accounts in Genesis, from which the affirmation of identity is traditionally drawn, the truth of being made in the image of God (1:17) or being filled with God's breath (2:7) is immediately coupled with the theme of vocation, the calling to be responsible actors in this world newly created by God $(1: 18 ; 2: 5)$. (p. 24)

Genesis 1:27-28 is often used in theological discourse regarding what it means to be human, and it keeps this correlation between personhood and calling intact.

There are many further notions and conceptions within Christian anthropology that can be utilised in theological discussions on human enhancement as well as many different interpretations of what it means to be created imago Dei. But for this contribution, I wish to focus on this aspect of vocation to be responsible actors. Future reflections could concentrate on the aspect of human suffering, mortality, limitations and restrictions, and whether any or all of these characteristics that currently mark human existence can be said to be necessary in order to be human. Greguric (2014:142) refers to Kurzweil's argument that it is possible for human beings to become immortal within the next 20 years thanks to reaching the summit of nanotechnologies and achieving a more profound understanding of how the human body functions. In addition, Kurzweil's transhumanist vision includes that, instead of 'being vulnerable mortals, we could become strong, invulnerable cyborgs or immortal minds living in an eternal, virtual world' (Coeckelbergh 2013:22).

This is intimately linked to the need for Christian theology to speak prophetically, also when it comes to issues of biotechnology and human enhancement. Is it possible to employ enhancement technology in a manner which is faithful to acting responsibly, also before God and according to Christian calling?

I have already referred to the expression often used in discussions, also in secular debates, namely that biotechnology is a means of 'playing God'. On one side of the debate, Audrey Chapman (1999:52) considers the term 'playing God' as a symbolic statement of unease or even caution against the farreaching power of contemporary biotechnology. Gleaves (2017) calls the normative assertion that 'humans should not play God', or for secular philosophers, 'humans should not interfere with nature', a 'Promethean' argument against enhancement:

These claims both hold that the way things are is the way things should be. Such an argument can serve as a priori moral proof by those who invoke it, though few invoking such arguments ever explain why playing God is wrong or why nature is correct. (p. 95)
Eberl also refers to the Promethean argument, noting that, while a specific form of enhancement could well be evaluated as being acceptable, the interplay between other aspects and contributing factors could lead to it being judged as morally impermissible. He provides the example of some types of enhancement that could wear down our admiration and enjoyment in 'the inherent "giftedness" of nature', and reveal that, at its core, it is merely a Promethean drive towards mastering nature (Eber 2014:291). John Danaher (2016:360) discusses Michael Sandel and Michael Hauskeller's notion of solidarity as opposition to enhancement where they claim 'that the pursuit of hyperagency will degrade social solidarity because it will undermine our appreciation for the gifted aspects of our lives'. Against these view, Danaher (2016:361367) argues that, even though there is value in social solidarity, the means that Sandel and Hauskeller emphasise for its diminishment is unlikely. In addition, enhancement could be calculated and steered in such a manner that solidarity could be protected.

This utilisation of the term 'playing God' could then be used to oppose both the development and utilisation of biotechnological knowledge and skills, also when it comes to human enhancement, on the basis that human beings are interceding onto God's territory and not taking our limitations into account.

One of the important religious feelings that Friedrich Schleiermacher identified, is the 'innate feeling of dependency' expressed rather importantly for an anthropological approach as 'creatureliness' (Migliore 2004:102). It would then appear that dependency and limitations are an essential part of what it means to be human and trying to overcome this, even in ways which are seen to be 'enhancement' would make us lose what it means to be human. In this regard, Reinhold Niebuhr (1996:168) asserts that sin is the result of human beings' anxiety over our own finitude and dependence, and states that it is for this reason that unbelief has frequently been emphasised in Christian orthodoxy as the root of sin or the sin which precedes pride. It is not anxiety itself that is the sin, but what this anxiety gives way to (Niebuhr 1996:183). Anxiety is then described to be both the source of human creativity and the temptation to sin. Human attempts to fight their own finitude will always be destructive and bring about pride and sensuality (Niebuhr 1996:185-186).

Daniël Louw (2008:312), on the other hand, designates this expression not necessarily as describing an 'objection to manipulating material of life or to resisting contemporary developments in molecular biology and gene technology'. He mentions further that it is also possible to view the statement 'playing God' as articulating profound marvel and unease, taking note of humanity being on the brink of understanding the essential machinery of life and how it works. In fact, this combination of awe and discomfort can be said to be comparable to Rudolf Otto's concept of the numinous, the mysterium tremendum et fascinans (McGrath 2007:453). It is in a similar vein that the Genetic Science for 
Human Benefit document of the National Council of Churches (USA) postulates through Chapman (1999) that creation, by divine power, is not static:

... but dynamic and ongoing. As creatures uniquely made in God's image and purpose, humans participate in the creative process through the continuing quest for knowledge, which now includes unraveling and learning to control the intricate powers compressed in genes of DNA molecules. (p. 44)

From this perspective, one might go so far as to say that not taking up the responsibility enshrined in this creative process, also through utilising the scientific tools at hand to become actively involved in creation, might rather be the failure to accept responsibility, to accept our vocation and calling.

Examining these two opposing perspectives in terms of human enhancement, also in particular conversation with Christian anthropology, is another field where much further research is necessary. It is not only human creation that are affected by enhancement technology, however, it is beyond the scope of this contribution to also address environmental implications. Humanity stand in 'relationship with creation, and as God's representative should maintain, rule and look after it' (Vorster 2007:20). It could be argued that enhancement forms part of maintaining and ruling creation, while the same argument could be used to make the case that humanity should not be so full of pride as to imagine that we could 'enhance' God's good creation. This could be another area that future research could focus on.

Christian anthropology is not the only doctrinal point of departure that future studies in this area might wish to take. Viewing enhancement from an eschatological perspective, examining whether we might perceive enhancement as a form of continuous creation, or humanity stepping up to our calling as co-creators, for example would also be an especially fruitful path that future research could take. However, to conclude this contribution, cn view of the issue of human dignity discussed previously as it is related to being created in the image of God, I would like to put forward one last aspect to be kept in mind in thinking about human enhancement from a theological perspective.

\section{Conclusion}

In this contribution I have indicated numerous aspects that future research could rewardingly focus on. To conclude, I will now turn to what, in my opinion, is one of the most important ethical challenges that enhancement technologies such as biotechnology, robotics and nanotechnology raises for the question of church and society, namely the possibility of enhancements increasing existing socioeconomic divisions and disparities.

Eberl (2014:291) remarks on this risk and states that 'if enhancements are available for only a select few who enjoy wealth or high social standing', societies could become socially disordered by an increase in socioeconomic discrepancy. Harsh social disruption would cause such enhancements to be deemed impermissible, 'or at least problematic in the absence of alternative social support mechanisms for the unenhanced to ameliorate the effects of such increased socioeconomic bifurcation' (Eberl 2014:291). Gavaghan (2007:172) also comments on the fear that disproportionate access to this form of technology could further exacerbate the pre-existing partitions. On the one hand, the risk exists in the possibility that concern and empathy for certain diseases could dissolve if the affluent were able to prevent these diseases in their children through the utilisation of enhancement technologies. These ailments could become 'low-class' diseases. In addition, if illness is thought of as something preventable that could have been avoided with the proper use of technology, social provision and care for the sick might also be lessened (Gavaghan 2007:172-175). Fukuyama (2002) further indicates that if:

wealthy parents suddenly have open to them the opportunity to increase the intelligence of their children as well as that of all their subsequent descendants, then we have the markings not just of a moral dilemma but of a full-scale class war. (p. 16)

Enhancement technologies would not cause these problems, as Kotzé (2016) postulates that:

... it should also be borne in mind that the wealthy already have more access to expensive medical procedures and better health care and that those who can afford to go to private clinics and hospitals are already in a much better position than those who are forced to wait in line in state clinics and governmentsponsored hospitals. (p. 72)

Rather than use this as an excuse to not address the ethical challenges brought on by the proposed biotechnological enhancements to humanity, I would like to argue that this should be even greater cause to reflect also theologically and ethically on the inequalities that exist in our societies.

This is also of particular interest for the discussion presented in this contribution drawing on Christian anthropology. Vorster (2007:20) notes that dignity is a common attribute of human beings, as we are all created in God's likeness. Our creation also as social beings, 'presupposes a right to freedom and equality ... Because all people are created in the image of God, all people are equal' (Vorster 2007:21). This equality is something that should be protected and defended, also if it appears that enhancement might threaten this God-given equality. Being created equal also implies that all human beings have equal worth. In addition to the possibility of the exacerbation of existing socioeconomic divisions, human enhancement also brings about the risk of human objectification.

Moltmann (1985:105) notes that it is possible for our likeness to God to be damaged and harmed through things like poverty, a denial of basic economic rights and especially, restrictions to access to resources. Etienne de Villiers (1993) states:

That health is one of the basic needs of human beings as image bearers of God and that fellow human beings have the obligation to provide adequate health care to those who fall ill, is something about which the Bible leaves us in no doubt. (p. 103) 
Ensuring equality, also in health care technology, is therefore of upmost importance.

Being created in God's image is a relational concept, referring not only to humanity's relationship with God, but also with each other. Disrupting these relationships through the possible enlarging socioeconomic divisions between people through the utilisation of enhancement technology, is a serious bioethical and theological question and, in my view, one of the most important aspects that future research should focus on.

\section{Acknowledgements Competing interests}

The author declares that she has no financial or personal relationships which may have inappropriately influenced her in writing this article.

\section{References}

Agar, N., 2004, Liberal eugenics: In defence of human enhancement, Blackwell, Malden, MA.

Agar, N., 2010, Humanity's end: Why we should reject radical enhancement, MIT, Cambridge, MA.

Bailey, R., 2005, Liberation biology, Prometheus, Amherst, MA.

Beck, U., 1992, Risk society: Towards a new modernity, Sage, London.

Berkouwer, G.C., 1962, Man: The image of God, Eerdmans, Grand Rapids, MI.

Bostrom, N., 2003, 'Human genetic enhancement: A transhumanist perspective', Journal of Value Inquiry 37(3), 493-506. https://doi.org/10.1023/B:INQU.00000 19037.67783.d5

Bostrom, N., 2005, 'In defense of posthuman dignity', Bioethics 19(3), 202-214.

Chapman, A.R., 1999, Unprecedented choices: Religious ethics at the frontiers of genetic science, Fortress, Minneapolis, MN.

Coeckelbergh, M., 2011, 'Human development or human enhancement? A methodological reflection on capabilities and the evaluation of information technologies', Ethics and Information Technology 13, 81-92. https://doi.org/ technologies', Ethics and Inforn
10.1007/s10676-010-9231-9

Coeckelbergh, M., 2013, Human being @ risk: Enhancement, technology, and the evaluation of vulnerability transformations, Springer, Dordrecht.

Danaher, J., 2016, 'Human enhancement, social solidarity and the distribution of responsibility', Ethic Theory Moral Practice 19, 359-378. https://doi.org/10.1007/ s10677-015-9624-2

De Gruchy, S., 2003, 'Of agency, assets and appreciation: Seeking some commonalities between theology and development', Journal of Theology for Southern Africa 117, 20-39.

De Villiers, E., 1993, 'Appropriate health care as human right: A theological perspective', in A.A. van Niekerk (ed.), Health care as human right, pp. 100-115, University of Stellenbosch, Stellenbosch.
Eberl, J.T., 2014, 'A Thomistic appraisal of human enhancement technologies', Theoretical Medicine and Bioethics 35, 289-310. https://doi.org/10.1007/ s11017-014-9300-x

Fukuyama, F., 2002, Our posthuman future: Consequences of the biotechnology revolution, Farrar, Strauss \& Giroux, New York.

Gavaghan, C., 2007, Defending the genetic supermarket: The law and ethics of selecting the next generation, Routledge-Cavendish, Abingdon.

Gleaves, J., 2017, 'Beyond Prometheus, strawmen, and science fiction: Ethicists and the moral debate over enhancements to human performance', Kinesiology Review 6, 91-98. https://doi.org/10.1123/kr.2016-0042

Greguric, I., 2014, 'Ethical issues of human enhancement technologies: Cyborg technology as the extension of human biology', Journal of Information, Communication and Ethics in Society 12(2), 133-148. https://doi.org/10.1108/ JICES-10-2013-0040

Harris, J., 2007, Enhancing evolution: The ethical case for making better people, Princeton University Press, Princeton, NJ.

Kirchhoffer, D.G., 2017, 'Human dignity and human enhancement: A multidimensional approach', Bioethics 31(5), 375-383. https://doi.org/10.1111/bioe.12343

Kotzé, M., 2016, 'Human genetic engineering and social justice in South Africa: Moltmann and human dignity, Acta Theologica 36(1), 70-78. https://doi. org/10.4314/actat.v36i1.5

Louw, D.J., 2008, Cura Vitae: Illness and the healing of life, Lux Verbi, Wellington.

Lüthy, C.H. \& Koop, B.-J., 2013, 'Towards Homo Manufactus? An introduction to this volume', in B.-J. Koops, C.H. Lüthy, A. Nelis, C. Sieburgh, J.P.M. Jansen \& M.S Schmid (eds.), Engineering the Human: Human enhancement between fiction and fascination, pp. 1-10, Springer Verlag, Berlin.

McGrath, A., 2007, Christian theology: An introduction, Blackwell, Oxford.

Migliore, D., 2004, Faith seeking understanding: An introduction to Christian theology, Eerdmans, Grand Rapids, MI.

Moltmann, J., 1985, God in creation: An ecological doctrine of creation, SCM, London.

Moltmann, J., 1999, God for a secular society: The public relevance of theology, Fortress, Minneapolis, MN.

Niebuhr, R., [1941] 1996, The nature and the destiny of man: A Christian interpretation: Human Nature, Westminster John Knox Press, Louisville, TN.

Nussbaum, M.C., 2002, 'Capabilities and human rights', in C. Cronin \& P. de Greiff (eds.), Global justice and transnational politics, pp. 117-150, MIT, Cambridge.

Nussbaum, M.C., 2006, Frontiers of justice: Disability, nationality, species membership, Harvard University Press, Cambridge.

Nussbaum, M.C., 2008, 'Human dignity and political entitlements', in Human dignity and bioethics: Essays commissioned by the President's Council on Bioethics, pp. 351-380, President's Council of Bioethics, Washington.

President's Council on Bioethics, 2003, Beyond therapy: Biotechnology and the pursuit of happiness, Washington, viewed 16 April 2018, from www.bioethics.gov

Sandler, R. \& Basl, J., 2010, 'Transhumanism, human dignity, and moral status', American Journal of Bioethics 10, 63-66. https://doi.org/10.1080/152651610 03714019

Singer, P., 2003, Shopping at the genetic supermarket, viewed 13 April 2018, from

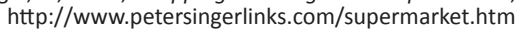

Stock, G., 2002, Redesigning humans: Our inevitable genetic future, Houghton Mifflin, Boston, MA.

Vorster, N., 2007, Restoring human dignity in South Africa, Potchefstroom Theological Publications, Potchefstroom.

World Transhumanist Association [now Humanity Plus], 2008, 'Transhumanist Manifesto', viewed 01 May 2018, from https://humanityplus.org/philosophy/ transhumanist-declaration/ 